Jean-Michel Johnston, Somerville College, Oxford

The Time and the Place to Network: Werner Siemens during the Era of Prussian

\title{
Industrialisation, 1835-1846
}

In early July 1846, the young Prussian lieutenant Werner Siemens visited the Berlin residence of Hofrat Soltmann, the father of one of his brigade comrades. There, he attended the trials which a clockmaker, Ferdinand Leonhardt, was conducting with a modification of a telegraph apparatus designed by Professor Charles Wheatstone of King's College London, and imported from England. ${ }^{1}$ As Werner later wrote to his younger brother Wilhelm, that day he 'found Leonhardt [...] in great difficulty because his newly constructed telegraph was making errors which he couldn't comprehend. As their cause was immediately clear to me, I showed him how he might avoid them' ${ }^{2 *}$ Thus, it seems, in a brief moment of inspiration Werner Siemens made his first contribution to the world of telegraphy.

Only a few hours, or perhaps days later, Siemens continued, 'frustration at my stupidity, or at least lack of intelligence, occasioned me to think a little more about telegraphy, whereby it was helpful to me to have been working on a history of electrical telegraphy for the annual report of the Physikalische Gesellschaft. And lo and behold, I arrived at truly brilliant results, which gave me a determined vision of recasting the whole system'. ${ }^{3}$ By mid-July, Siemens' first telegraph apparatus was ready to be trialled. As his mind turned to the improvement of existing techniques of telegraphy, he asked that Wilhelm, who was based in London, enquire about existing English patents in this domain, and in particular those which Professor Wheatstone might already possess. ${ }^{4} \mathrm{With}$ this foray into the English market, he had sown the seeds of the global Siemens enterprise whose renown endures to this day.

Finding ourselves in medias res, it is tempting to view these events of July 1846 from one of numerous familiar perspectives on the Vormärz period in Germany, each of which might suitably contextualise the moment. The trials taking place at Hofrat Soltmann's house, for instance, were part and parcel of the Prussian state's efforts to 
stimulate technological progress, often through the importation of foreign, usually English, models. ${ }^{5}$ In this particular case, the state institution bringing together the actors in question was the military establishment. Not only was Werner a brigade comrade of Soltmann's son, he had also contributed to the clockmaker Leonhardt's work for the Artillerie PrüfungsKommission. ${ }^{6}$

Siemens' moment of inspiration, meanwhile, appears to gives us a brief insight into the mindset of a restless innovator. He can, and indeed has been inscribed in the list of quasi-autodidactic entrepreneurs, alongside such figures as Krupp and Borsig, who helped lay the foundations of Germany's industrialisation. ${ }^{7}$ Siemens' mention of the Physikalische Gesellschaft, meanwhile, points to the context of middle-class sociability in the early nineteenth century, as well as to the role of scientific knowledge in the process of industrialisation - particularly at a time when the landscape of scientific communication was changing, and new technical professions emerged. ${ }^{8}$

Looking backwards and forwards in Siemens' biography as an exemplar of German industrial success, still further historical perspectives might also focus more clearly on various aspects of his life trajectory. Rather than allow Siemens' later influence to orient our historical viewpoint and select one of these narratives, however, this article explores their entanglement. ${ }^{9}$ It spotlights the social contacts, like those between Siemens, Leonhardt, Soltmann and the Physikalische Gesellschaft, which connected the worlds of technological innovation, science, enterprise, and state administration in Vormärz Prussia.

Indeed, Siemens' richly documented and multifaceted life affords the historian a unique opportunity to explore the forces behind the early phase of industrialisation in Prussia. A long tradition of scholarship, from William O. Henderson, Ulrich Peter Ritter and Wolfram Fischer to Wilhelm Treue, has emphasised the central role which the state necessarily played in this process, seeking to close the development gap between Germany and its Western neighbours, Britain in particular. ${ }^{10}$ Fischer identified four principal means through which the government fostered economic development: legislation, administration, 
enterprise and consumption. These included, respectively, the Stein and Hardenberg reforms of 1808-1817; the establishment of the Technische Deputation für Handel und Gewerbe, and of Christian Peter Wilhelm Beuth's Gewerbe-Institut and Verein zur Förderung des Gewerbfleißes in 1819/21; the Seehandlung's investment in diverse local manufacturing and industrial businesses; and, finally, the demand for goods emanating from the court and the army. ${ }^{11}$ Yet although Werner Siemens benefitted in some way from a number of these initiatives, he was by no means a product of them.

The 'statist' historiographical tradition places considerable emphasis upon the achievements of a reforming bureaucracy, men such as Beuth and Gottlob Johann Christian Kunth, but leaves little room for the agency of entrepreneurs themselves. Qualifying the state's interventionism, therefore, Ilja Mieck described the Prussian government's policy as rather oscillating between liberalism and mercantilism, and concluded that by the $1840 \mathrm{~s}$ the private sector was increasingly trusted to take its own initiatives. ${ }^{12}$ Hans-Ulrich Wehler asserted that the state established a 'framework' which did no more than not hinder development. ${ }^{13}$ Wilhelm Treue himself admitted that there were some domains in which Beuth's education reforms had been limited, in the agricultural and natural sciences in particular. Trained instead at the Vereinigte Artillerie- und Ingenieur-Schule, Werner Siemens had thereby 'found a second or third educational path to technology and science'. ${ }^{14}$

Tracing Siemens' footsteps along this path, this article highlights the opportunities which existed for entrepreneurs to wind their way through state and society in Prussia during the 1840s. It builds upon the efforts of historians such as Jürgen Kocka, who emphasised the agency of entrepreneurs in the economy, rescuing them from the anonymity with which they also seemed threatened by the autonomous economic forces of Marxist theory. In the 1970s, Kocka searched for patterns in the socio-economic and professional background of Prussia's early entrepreneurs, and concluded that they often had origins among the Handwerker, or trading classes. ${ }^{15}$ In his earlier study of Berlin, Hartmut Kaelble argued against the notion that economic liberalisation facilitated social mobility, noting 
that entrepreneurs migrating to the city were themselves most often descended from entrepreneurs, whether merchants, bankers or manufacturers. ${ }^{16}$ Studies of the Techniker who were directly trained in state-funded institutions, such as Beuth's Gewerbe-Institut, have come to similar conclusions. ${ }^{17}$ Such prosopographical research has enriched our understanding of Germany's emerging Wirtschaftsbürgertum, to which Siemens undeniably came to belong, but whose social roots and career paths he did not share. ${ }^{18} \mathrm{His}$ parents closely associated with the Bildungsbürgertum, and he himself aspired to an academic, rather than a professional or technical education. ${ }^{19}$

Instead, the earliest biographies of Werner Siemens, published in 1916 to commemorate the hundredth anniversary of his birth, attributed his success not to the institutional or socio-economic environment, but to his exceptional personal qualities. In line with contemporary celebration of history's 'great men' Artur Fürst and Conrad Matscho $\beta$ spotlighted his gifts in the scientific and technical domains, his patriotism, and depicted him as a self-made man. ${ }^{20}$ Almost a century later, Wilfrid Feldenkirchen similarly emphasised Siemens' talents but, in a reflection of changing historiographical trends, focused upon his entrepreneurial flair, arguing that he was a modern, 'forward-looking', and internationally-oriented businessman. ${ }^{21}$ Jürgen Kocka, on the other hand, recognised the influence of Werner's military training upon his managerial style. His magisterial account, however, focuses upon the putative 'bureaucratisation' of the Siemens firm as it ascended to a dominant position in the German electrical industry in the decades following its establishment in $1847 .{ }^{22}$

In light of his later success, Werner Siemens appears as the epitome of the entrepreneurial class at the heart of Prussian industrialisation, and yet he consistently defies categorisation. On one hand lay the socio-economic structures and state institutions which provided the groundwork for industrialisation. On the other, Siemens' undeniable yet also intangible qualities which enabled him to pursue inventions as diverse as 'galvanic' gilding and the production of artificial stones, whilst hunting down opportunities to market them. 
Between them, this article argues, lay the social networks which Siemens used to connect to institutions, entrepreneurial groups and scientific circles. Through his correspondence during the late 1830 s and early 1840 s, we catch a glimpse of the people and places bringing together the many different actors at the heart of Prussian industrialisation.

In order to explore these connections, this article draws upon the insights gained from the increasing attention recently given to networks in various sub-fields of historiographical enquiry. ${ }^{23}$ In particular, it focuses upon social networks as a basis of interaction which not only strengthened the bonds between individuals in the same group, but also served as bridges between them. Indeed, since the publication of Mark Granovetter's article on the 'strength of weak ties' in 1975 and the emergence of related 'small world' theories, sociological inquiries have suggested that seemingly marginal connections between individuals belonging to separate groups are in fact the crucial links which weave them together to form the fabric of society. ${ }^{24}$

Siemens' experience in 1840s Berlin illustrates the importance of these two functions of social networks and his ability to exploit both strong and weak ties. The military institution, the Physikalische Gesellschaft, the Polytechnische Gesellschaft, and to a great extent his own family constituted 'clusters' of individuals with whom he shared common interests, affiliations and ambitions, and to whom he could turn for resources of various kinds. Belonging to these different groups simultaneously, on the other hand, he and some of his acquaintances also constituted important connections between them, and indeed with others. Through their interactions, Siemens and his contacts highlighted the zones of porousness in the boundaries of social circles and state institutions.

Taking this approach shifts our perspective on some of the central questions in the historiography of early Prussian industrialisation. As Eric Brose has shown, behind the monolithic façade of state institutions and policies during the Vormärz lay the factions and coalitions within the Prussian state departments engaged in technological development, and the 'linking personalities' between them. ${ }^{25}$ Without denying the power of the state as an 
abstract force, Brose's work also suggests that it might usefully be understood as a cluster of individuals engaging in social interactions with other actors in the process of industrialisation. As James Brophy has shown, for instance, the construction of Prussia's railway network involved active negotiation between businessmen and state representatives. ${ }^{26}$

Acknowledging the social role of military or bureaucratic actors enables us to account for exchanges between the state and 'civil society'. It was as a lieutenant in the Prussian artillery regiment that Werner Siemens joined the Physikalische Gesellschaft, introducing a seemingly foreign element into a characteristically bourgeois, learned society. The same networks of correspondence and sociability which have long been recognised as central to intellectual exchange and to the formation of an independent public sphere also created opportunities for new connections to be made. ${ }^{27}$ Borrowing from Brian Vick's description of salon culture in Congress Vienna, they allowed for both the 'congregation of the like-minded and the mingling of the unlike'. ${ }^{28}$

Social networks similarly served as a source of innovation as well as stability among entrepreneurs, specifically. Networks have been understood as a means of securing access to capital, information, and markets throughout history, and kinship ties are perhaps most prominent among the social structures which support the development and expansion of businesses. ${ }^{29}$ Indeed, the two most recent biographies of Werner Siemens and his brother Carl have placed the close relationship between all the Siemens siblings, of whom Werner was the second eldest, at the heart of the family firm's success. ${ }^{30}$ In the early 1840 s, Werner's younger brother Wilhelm was a crucial ally with whom he could discuss his innovations, and whose emigration to England provided him with a connection to an important foreign market. Carl too later joined the firm, helping to expand its activities into Russia in the 1850s. But other social networks could also support business in different ways, facilitating access to materials, and providing feedback on entrepreneurial initiatives. ${ }^{31}$ In a similar way, as this article will demonstrate, alongside his family Siemens 
also benefitted from the semi-formal Polytechnische Gesellschaft in Berlin, where he found support, creative input and constructive criticism of his ideas.

The networked nature of society undoubtedly bears a somewhat universal quality, but its prominence during the 1840s, and in Berlin specifically, is striking. By then, the market economy unleashed during the Reform Era had begun to bear its fruit, creating both opportunities and difficulties for state and society, and social networks became a means for both to negotiate those consequences. They especially provided those groups which emerged outside the traditional organisational structures of society with a means of accessing wider resources whilst simultaneously protecting common interests.

By engaging in exchanges with different clusters of individuals, Werner Siemens was able to plug into the thickening administrative, professional, and financial 'networks of means' which Jerrold Seigel has identified as the key to the power of the modern European Bourgeoisie. ${ }^{32}$ As an officer, entrepreneur, aspiring academic, and family man, Siemens demonstrated that these networks could themselves be connected. It was the interaction of these diverse forces which underpinned industrialisation as one facet of the 'great transition' to a modern economic order. ${ }^{33}$ Inevitably, some of the ties in question were indeed 'weak', and should not overshadow the strength of bonds within social circles and institutions. But it was also through the chance meetings, face-to-face interactions, and spontaneous encounters which have left only ephemeral traces, that some of the most important connections could be made.

Social change during this period was of course supplemented by growing political agitation. Siemens found himself at the heart of a city bustling with political activity, and yet his correspondence leaves no suggestion that he was preoccupied with political or social questions. ${ }^{34}$ Only in 1848 would Siemens begin to comment explicitly upon current affairs, hinting at his liberal views and pointing towards his later role as co-founder of the Fortschrittspartei in 1861. It is quite possible, however, that the same social circles and institutions to which he belonged provided opportunities for political discussion. The social 
networks between them underpinned the changing state-society nexus at a transitional moment in the industrialisation of Prussia during the Vormärz.

Perhaps the most tangible and institutionalised network to contextualise the events of July 1846 is that of the Prussian military establishment. The clockmaker, Ferdinand Leonhardt, had been conducting his trials on behalf of a commission established in 1844 to investigate developments in the realm of electrical telegraphy. As this field had been the preserve of General-Major O'Etzel, since the introduction of optical telegraphy in 1832, these trials took place under the auspices of the Ministry of War. ${ }^{35}$ Having collaborated with the clockmaker and met Soltmann's son in his capacity as an officer, it was within this broad military context that Werner found himself at the Hofrat's home.

Viewed differently, however, Soltmann and Leonhardt both constituted contacts between the military establishment and the realm of professions and entrepreneurship. The former was an apothecary also involved in the production of artificial mineral water, the latter one of the most prominent clock manufacturers (Fabrikanten) to have sprung up in Berlin since the law introducing Gewerbefreiheit in $1810 .{ }^{36}$ Both belonged to groups of innovators and experts on specific technical issues who lay outside the institution, but to whom the army and its technological commissions turned for assistance. By interacting with individuals such as these, Siemens and his fellow officers trained in the Prussian artillery regiment gained access to broader networks of knowledge circulation.

When Siemens had left his family's modest estate in Mecklenburg at the age of eighteen to join the Prussian army, his decision had been primarily strategic. By his own account, he had always shown an interest in science, and had long hoped for an education at the Prussian Bauakademie, the traditional seat of applied science. However, his parents' inability to cover the costs involved had led him to seek his scientific and technical training elsewhere. Initially turned down by the Ingenieurkorps, he eventually received a place at 
the Vereinigte Artillerie- und Ingenieurschule (henceforth VAIS) in Berlin. ${ }^{37}$ It was here, between 1835 and 1838, that he became a second lieutenant. The education he received at the VAIS, as he was to discover, would introduce him to key figures in science and enterprise, and to the social dynamism of the burgeoning city of Berlin.

As a lieutenant trained in the artillery corps, Siemens already appears to diverge from the majority of his fellow entrepreneurs and engineers. Research on the role of Techniker during the industrial revolution has spotlighted either the autodidacts or the products of the state's institutions - the provincial Gewerbe-Schulen and the GewerbeInstitut in Berlin in particular. ${ }^{38}$ Hartmut Kaelble recorded only one entrepreneur in Berlin whose background was as an officer, and this was presumably Siemens himself. ${ }^{39}$ Very little attention, it seems, has been paid to the influence of military education, particularly in the engineering and artillery corps, upon the process of industrialisation.

The traditional interpretation suggests that ' $[\mathrm{m}]$ ilitary standards and patterns $[\ldots]$ were clearly distinguished from the standards and behaviour of the capitalist entrepreneur', though Jürgen Kocka himself argued that the military habits drilled into Werner as an officer carried over into his managerial style. ${ }^{40}$ Clearly, however, the knowledge imparted by certain army regiments, and their wide-reaching networks of contacts, could provide technical, logistical, and perhaps even financial support for the entrepreneurial pursuits of their recruits. As this article will highlight, Siemens was not the only officer harbouring such ambitions.

Although Werner later claimed to have consciously neglected the military aspects of his training, he was of course influenced by the culture it fostered. As he gladly admitted in his recollections, for instance, he and his friend Wilhelm Meyer regularly took part - if only as Sekundanten - in the duels of honour which characterised both military and middleclass culture in mid-nineteenth century Germany. ${ }^{41} \mathrm{He}$ also disapproved of his younger brother Wilhelm's desire to work in trade as he 'shared the Prussian officers' dislike of the merchant class', an outlook which also conformed to that of his parents. ${ }^{42}$ 'Schaffen ist 
besser als Schacher', his father had once admonished him. ${ }^{43}$ Here too it might be added, however, that his father's preference for the productive trades differs from the traditional condescension which the Bildungsbürger are said to have shown towards them. ${ }^{44}$

Significantly, he joined the VAIS and artillery regiments at a time of only recently renewed interest in, and respect for this branch of the army. Until the 1830s, the bourgeois composition of the artillery, and its concern for crude technology had been the source of disdain on the part of a traditionally aristocratic officer corps still very much attached to a quasi-feudal vision of honour and medieval warfare. Of the great reformers, only Scharnhorst had placed considerable value in this 'step-child' of the Prussian army, but the Greek crisis of the late 1820 s had highlighted the need to develop new technologies. ${ }^{45}$ It was within this context of revival that commissions had been set up, such as the one overseen by O'Etzel and researching the introduction of telegraphy. ${ }^{46}$

In the mid-1830s, therefore, Siemens joined a corps whose leader, Prince August, encouraged an atmosphere of innovation and nonconformity vis-à-vis superiors, particularly within the Artillerie Prüfungs-Kommission. ${ }^{47}$ His training was also largely conducted alongside bourgeois officers, whose liberal political views he noted and adhered to, and in whose company he would at least once fall foul of the law. The expectations which the authorities now placed upon the artillery corps had opened their channels of communication with a middling, entrepreneurial and liberal stratum which had previously been shunned, creating new opportunities for its officers.

The VAIS was also a source of acquaintances and friendships which were to carry over into Werner's civilian life. His batman in Berlin, Daniel Hemp, was to accompany him on a number of telegraph laying expeditions in later years. ${ }^{48}$ Besides Carl Soltmann, however, of greatest lasting significance was his friendship with Wilhelm Meyer, who rose to the rank of Oberstleutnant, and with whom Siemens stayed in close contact throughout his life. The two men shared living quarters when stationed in Magdeburg in the early 1840s, and both left the army at the same time in 1849 to take on complementary positions 
in the private and public spheres of telegraphy. ${ }^{49}$ Eventually, Meyer was to leave the civil service for a managerial position in Siemens' business.

The curriculum followed at the VAIS, meanwhile, covered the subjects of artillery, the art of fortification, and military history, but also French, geography, maths, physics and chemistry, among other subjects. ${ }^{50}$ This variety of disciplines must have inspired Siemens' future experiments, but it also introduced him to his teachers, among whom the mathematician Martin Ohm, the chemist Otto Linné Erdmann, and the physicist Heinrich Gustav Magnus. Ohm, younger brother of the famous physicist, was to become a professor at the University of Berlin in 1839, Erdmann was a professor at the University of Leipzig, and Magnus, already assistant professor at the University of Berlin, would eventually be rector of the institution.

Due to a competitive job market in this period, particularly among physicists, many academics were required to teach in Germany's different Gymnasien, polytechnical schools, and other educational institutions as they waited for a university appointment. Georg Ohm himself had taught at the VAIS before moving to the Nuremberg Polytechnische Schule in 1833, and these wanderings served to diffuse knowledge outside the confines of the university, blurring the boundaries between the academic and 'lay' worlds. ${ }^{51}$ During their time at the VAIS, Siemens' instructors created a link between academic and military networks, and Gustav Magnus in particular would later provide him with access to a crucial cluster of young scientists.

In a similar way, the technological commissions established by the army sought talent beyond the establishment. The telegraph commission's collaboration with Leonhardt and Soltmann was symptomatic of a growing dependency upon private contractors during the 1840s. It was within this context that the Ministry of War, struggling financially, and unable to rely either upon its own manufactures or upon the trained gunsmiths who traditionally worked for it, placed its first order with Alfred Krupp in $1846 .{ }^{52}$ The military mining corps, meanwhile, having long refused to adopt new methods of vertical mining 
and coke puddling, faced direct competition from the likes of Franz Haniel. ${ }^{53}$ These examples suggest that the state's ability to promote industrialisation had reached its limit, and as the military authorities were no longer able to rely upon the corporate structures of production, they reached out to a network of independent entrepreneurs to secure their position within a market economy.

A crucial link between these two groups was the Technische Deputation, which regularly received and assessed patent requests from a variety of applicants. When O'Etzel's commission began investigating electrical telegraphy in the early 1840 s, for instance, the Deputation was also sifting through a variety of related innovation proposals. The applicants ranged from foreign agents requesting permission to import a telegraph apparatus, through merchants, and even high school teachers such as August Kramer in Nordhausen. ${ }^{54}$ Under Beuth, the Technische Deputation had become a crucial nexus through which innovators seeking approval for their projects connected with the state.

By the 1840s, a constellation was forming between this department, entrepreneurs and military commissions. Indeed, it was the apothecary Soltmann himself who, in 1841, applied for and obtained an Einführungspatent from the Technische Deputation to import Charles Wheatstone's telegraph apparatus from England. ${ }^{55}$ The apparatus, brought to Prussia on this individual's initiative, then made its way into the hands of the clockmaker Ferdinand Leonhardt (perhaps at Soltmann's suggestion), who was conducting research on behalf of O'Etzel's Telegraphenkommission. Being acquainted with both Leonhardt and Soltmann through the army - among other contexts - Siemens found himself contributing to the clockmaker's work on Wheatstone's apparatus in July 1846. It was then as independent businessmen that both men turned once again to the Deputation to patent their inventions. Whilst the military establishment certainly shaped Siemens' mind and cultural outlook, therefore, it was also the first dense cluster of individuals to which he was introduced in Berlin, and through which he was already tied into other scientific and entrepreneurial networks. 
Many of the connections which Werner was able to make during his time at the VAIS from 1835 to 1838 were due to the proximity of those involved within Berlin. Upon completing his training, Werner was obliged to leave the city, being stationed first in Magdeburg, and then in Wittenberg, but it was in Berlin that he saw his future. There lay not only the core of the military establishment and the organs of government, but also the seat of academic learning and growing communities of young scientists and industrial innovators. In the early 1840 s, therefore, when Werner began to seek out opportunities to profit from his various experiments, Berlin came to occupy an increasingly prominent role as a market for knowledge, business and acquaintances.

Upon leaving the VAIS in 1838, Siemens began a frenetic search for lucrative inventions or innovations, spurred on by the death of both his parents in 1839/40 which left him to a great extent responsible for his eight younger siblings. Being stationed at a distance from the people and institutions he had discovered in Berlin, it was his family relations which tied him to developments in science, technology and enterprise. Whilst based in Magdeburg, for instance, the example of another artillery officer in the family, his cousin Adolph Siemens, who had helped develop firing mechanisms for rifles and pistols, encouraged Werner to experiment with explosives. ${ }^{56}$ His brother-in-law, August Himly, meanwhile, was a Privatdozent in physics at Göttingen, and with his stimulation and advice, Siemens began to experiment with new methods of electrolysis. ${ }^{57}$ In the future, Werner's family would repeatedly be his means of access to information and markets beyond the reach of his immediate circles.

After a brief spell in Wittenberg, Siemens once again moved to Magdeburg to serve a short sentence for participation in a duel, and he now began to feel his frustration at being relegated to a peripheral location. This was not merely the expression of a youthful desire for the vibrancy of a capital city, however. Werner's attempts to keep abreast of scientific developments and to obtain the necessary equipment for his experiments were being 
affected. As he complained to his brother, 'Magdeburg really is a depressing backwater [ein fatales Nest...] One cannot obtain anything here, it is mostly all expensive and of poor quality. ${ }^{58}$ In 1842 , however, he was finally transferred to Spandau, on the outskirts of Berlin, where his talents as a technician were to be applied to the manufacture of fireworks. Edging closer to the capital, Siemens could now reconnect with his erstwhile acquaintances. 'No doubt you are still in Spandau and often come to Berlin and so also to see my parents', Carl Soltmann wrote to him. ${ }^{59}$

When his younger brother Wilhelm entered the world of industry, Werner was drawn more firmly into entrepreneurial networks. Wilhelm had studied at a trade school in Magdeburg, then in Göttingen, before returning to the former for an apprenticeship. For his part, Werner continued with his own experiments in electrolysis, particularly the elaboration of new gilding methods, for which he applied and obtained a patent. ${ }^{60}$ But he was now also engaged in helping Wilhelm develop a 'chronometric governor' [DifferenzRegulator], a mechanism which would help regulate the running of steam engines. ${ }^{61}$ Werner's army comrade Meyer recommended turning to Adolph Brix - a FabrikenKommissions Rat and engineer - and Beuth in Berlin for advice in the matter, luring Siemens once again to Berlin and its key personalities. ${ }^{62}$

His relief was clear therefore, when he received news of his assignment to the capital, in September 1842. Writing to his brother he admitted that 'the posting to Berlin is very agreeable to me, particularly when compared with the awful stay in Wittenberg which I was expecting. For our various efforts, too, it is very good that I should stay close to the source' ${ }^{63}$ In Siemens' mind, Berlin would be the fount of future opportunities.

The city witnessed a flurry of activity in the 1840s, as the incipient railway industry stimulated the establishment of machine construction factories there, and its role in the industrialisation of Germany is widely accepted. It was here that Franz-Anton Egells, and later his two former apprentices August Borsig and Johann Friedrich Wöhlert established their businesses. As Jürgen Kocka posited, it was in Berlin that one could perhaps most 
directly experience the puncturing of the old estate-based society which produced the conditions for individuals to establish new contacts and networks. ${ }^{64}$ Ilja Mieck, argued that the state's efforts to stimulate private industry in the 1820 s and 1830 s were most fruitful in Berlin both because the power of the guilds had been broken and 'due to the narrow economic as well as locally induced contact of tradesmen with each other, and to the presence of the state's industry-stimulating institution in one place'. ${ }^{65}$ The dismantling of the pre-existing socio-economic framework left more space for the creation of new relationships.

Indeed, as Ingrid Thienel has shown, between 1837 and 1846 the city experienced its first period of rapid population growth during the nineteenth century, from 280,000 to 400,000 inhabitants. It was to be Central Europe's earliest and fastest growing city, following in the footsteps of London and Paris in attracting a constant influx of workers and entrepreneurs from outside. ${ }^{66}$ Once they had settled in Berlin, Kaelble argued that entrepreneurs were met with considerable resistance from local corporations, and instead cultivated social, often familial relations primarily within their group. ${ }^{67}$ Certainly, as the example of the Polytechnische Gesellschaft will show, the social and economic insecurity which entrepreneurs experienced in an expanding city made them particularly reliant upon social networks as a source of stability. On the other hand, Nadja Stulz-Herrnstadt has shown that the elite members of Berlin's Ältesten der Korporation der Kaufmannschaft owed their success to a remarkable social flexibility and to the extent of their 'Verkehrskreise' ${ }^{68}$ Like its Western neighbours, Berlin had begun to display the characteristics of the modern city as a 'network of networks' which served both to strengthen and to diversify social ties. ${ }^{69}$

The geography of the city itself encouraged contact between state institutions, scientific circles and entrepreneurial groups, enabling Siemens almost literally to navigate between the administrative, professional and business networks which were concentrated there..$^{70}$ As a second lieutenant, he worked and was housed in the centre of Berlin, thanks 
to the military's domination of the city's central quarters. The VAIS which he had attended between 1835 and 1838, was situated at the western end of the city's main thoroughfare, Unter den Linden, near Brandenburger Tor. When he returned in 1842, he was assigned to the Artillerie-Werkstatt, for which the address is listed as Dorotheenstrasse, practically opposite the VAIS. Over the next few years, he was registered first at the artillery workshop at the eastern end of Unter den Linden, am Kupfergraben, and later a little further north of the city centre, at Louisenplatz (now Robert Koch Platz). ${ }^{71}$

As Berlin grew around this military core during the period, travelling from one of the artillery's urban nodes to another placed Siemens at the heart of a cultural, economic and political hub. Leaving the VAIS to amble down Unter den Linden, he passed by the gates of the relatively new University of Berlin where he attended lectures in the early 1840s. Reaching the armoury at the avenue's eastern end, he could spot Schinkel's recent masterpiece, the Bauakademie, taunting him for never acceding to the ranks of its graduates. As evoked below, it was also here that his contacts in the Physikalische Gesellschaft gathered for their discussions. At Louisenplatz, on the other hand, he brushed the edges of the industrial district around Chausseestrasse, where Borsig had established his machine factory. And en route to the meetings of the Polytechnische Gesellschaft in the south of the city, he would cross the Gendarmenmarkt where Bruno Bauer and the Young Hegelians deliberated at Hippels Weinstube. ${ }^{72}$

In 1845 , it was when he 'went on a stroll through the Tiergarten with all the officers of the artillery workshop after work' that he came to hear a speech from Johannes Ronge, the priest behind the emerging German Catholic movement, whose support for democratic revolution was causing political agitation in the city. The experience, he explained, was unusual as 'until then, one was not used to public speaking in Prussia', leading him and all of his fellow officers to sign a petition which was being circulated, for which he was later reprimanded. ${ }^{73}$ The incident is the only direct evidence from this period of Siemens' interest in the movement of opposition to the government. However, it demonstrated that 
political discussions and ideas could transcend particular social circles and quite literally be carried through the city by the movement of people tied to different networks.

Reflecting these changing times, in 1839, Franz Krüger revised his painting 'Parade Unter den Linden', expanding the space occupied by a bourgeois public sphere, whose members look on as a neatly structured army marches by - two worlds cohabiting in Berlin. ${ }^{74}$ Siemens had indeed settled in a city which was witnessing a reconfiguration of the state-society nexus, but his experience revealed that quite literal avenues of communication existed between and within these groups. The thickening administrative, professional and financial networks through which resources were mobilised, passed through social hubs anchored in particular sites. Walking through the city as an officer, Siemens moved between these hubs, enacting his own social journeys between the flourishing industrial, academic and military networks which he utilised. No wonder, then, that once his business outlook improved in 1846, he asserted: 'I do not want to leave Berlin at all, nor can I' ${ }^{75}$

Within weeks of arriving in the Haupt- und Residenzstadt, Werner Siemens had joined a group of local artisans, Techniker, and even scientists who had formed the Polytechnische Gesellschaft a few years earlier. The society had been founded in 1839 upon the initiative of Nathan Mendelssohn, a lesser-known son of Moses Mendelssohn, who became an engineer, chief-inspector of the Royal Mint, and Stempel-Revisor ${ }^{76}$ Its earliest members represented a broad spectrum of trades, and included the renowned Berlin clockmaker Tiede, as well as J. C. Freund, one of the earliest machine constructors in the city. The Polytechnische Gesellschaft was the very first truly independent association of diverse private entrepreneurs, and remained so even as it gained membership of the statesponsored Verein zur Förderung des Gewerbefleißes in Preußen in $1840 .{ }^{77}$ As such, it helped its members navigate the choppy waters of a liberal market which had been set free from the restrictions, but also the protection of the guilds. ${ }^{78}$ 
When Werner joined in 1842 , the society counted around 250 primarily local members, and held meetings twice a month on a Thursday, at which its members were invited to present and listen to lectures on each other's technical interests and investigations. ${ }^{79}$ The society also acquired a growing collection of journals which its members could consult at all times, and extracts of which were presented at their meetings. By all accounts, the Polytechnische Gesellschaft was more than merely a nominal, loose grouping of individuals. Already in 1840, enough members were interested in meeting regularly for an informal secondary session to be held every other Thursday, and by 1842 the meetings were so well attended that tobacco and refreshments were banned, as they tended to cause too much disruption. ${ }^{80}$ The meetings were not held in a fixed location, but between 1842 and 1845 they most often took place on Krausenstrasse or in the rooms of the Urania society on Kommandantenstrasse, both on the southern edge of the inner city. ${ }^{81}$

From the time Siemens joined the Gesellschaft in 1842, he and his younger brother Wilhelm exchanged extensive correspondence regarding the innovations which they were both pursuing. Between 1842 and 1846, their projects were to revolve around four main fields: machine regulation (Wilhelm's Differenz-Regulator), printing, the production of 'artificial stones', and gold- or nickel-plating, the latter based on Werner's experiments in electrolysis. Once Wilhelm settled in London in 1843, the two brothers were to become one another's point of contact with the distant clusters of individuals to which each belonged. Just as Wilhelm channelled technical and market information from England to Berlin, so Werner used his contacts in the Prussian capital to help inform his brother's decisions. Whilst Wilhelm patented and then sold Werner's 'galvanic' gilding process in London, for instance, Werner turned to his colleague Ferdinand Leonhardt for help in producing the pendulum in his brother's Regulator. 
Meanwhile, Werner's web of contacts in Berlin was widening, and from 1843 he became a particularly active member of the Polytechnische Gesellschaft. Between March 1843 and March 1845, he gave eight lectures at the society's meetings. ${ }^{82}$ In 1844 , the records show that a certain 'Himly aus Göttingen' came to speak at the society, no doubt arranged by Werner, who wrote of his brother-in-law's visit around the same time. ${ }^{83}$ The proceedings of the society also confirm that he began to devote much energy to answering individual members' questions. The Polytechnische Gesellschaft had instituted a system whereby members could pose questions to their colleagues, in a 'Fragekasten', and each was free to respond if they felt qualified to do so. Siemens, for instance, intervened on the issue of electrolysis and gilding, as well as Daguerreotypes.

As an arena for the exchange of knowledge, the society struck a tense balance between constituting a 'closed circle' and an 'open network', particularly when it came to business. ${ }^{84}$ On one hand, the presentations and questions which the members exchanged were a means of introducing their ideas to a potential market and to other experts. Some of the questions could also be of a practical nature: for instance, whether the 'Grundri $\beta$ der mechanischen Technologi [sic]' by C. Karmarsch would be recommended for selfteaching, or whether 'steel from the Krupp factory could also be bought in Berlin' ${ }^{85}$ Twice, moreover, the society sponsored young apprentices to attend their meetings, demonstrating its desire to reach out to local future tradesmen. ${ }^{86}$ Then, when preparing for the industrial exhibition of 1844 , the society decided that its members should present their work as individuals, rather than as representatives of the group. ${ }^{87}$ In this sense, the Polytechnische Gesellschaft represented a modern, liberal conception of enterprise, independent of the state and encouraging the circulation of expertise.

On the other hand, the society also mitigated against the negative consequences of a free market economy. In 1842, for instance, the sanctity of intellectual property was underscored when an argument arose as one member published another's work, without 
first obtaining permission. ${ }^{88}$ From 1843 , members were given entry cards, the rules for inviting guests were tightened and, until 1845 , the assembly repeatedly voted against the publication of their proceedings. ${ }^{89}$ These measures somewhat restricted the openness of the network, ensuring that ideas and innovations did not reach the market without proper attribution and compensation.

In this respect, the establishment of the Polytechnische Gesellschaft paralleled the growing opposition to the state's liberal economic policies which surfaced in the $1840 \mathrm{~s}$. However, while the combination of traditionalist defence of the guilds and some businessmen's criticism of state interventionism led to the somewhat inconclusive compromise Gewerbeordnung of 1845, the members of the Polytechnische Gesellschaft used the association as a means of negotiating a position between the benefits of unrestricted enterprise and the dangers of open competition. ${ }^{90}$

From this perspective, the invitation which the society extended to young apprentices was also a means of providing them with the knowledge, recognition, protection and contacts which they might no longer find in the guilds - particularly as a glut of Handwerker saturated the market. These comforts benefitted other entrepreneurs too. In particular, unlike in Britain, the patenting process introduced in 1815 as part of Hardenberg's reforms afforded them little protection of their intellectual property, on the grounds that the innovations so crucial to industrial progress should be shared for the benefit of all. ${ }^{91}$ In 1847, the Franco-Belgian inventor and activist Marcellin-Ambroise Jobard, who campaigned against economic liberalism and free trade, presented a draft bill for consideration by the society which proposed that the length of a patent be extended to 99 years. The matter was not discussed any further on that occasion, but given that patent legislation featured in the Gesellschaft's debates in 1850 and Siemens' later agitation for patent reform, it is likely that such political issues made their way into the society's conversations. $^{92}$ 
Siemens, for his part, certainly took advantage of the forum which it provided to encounter, borrow and trial fresh ideas. 'I could tell you about a number of new, truly charming things which I have in part discovered from others, partly invented myself', he wrote to Wilhelm in $1845 .{ }^{93}$ When Werner brought up his interest in the Scotsman Stirling's 'Luftmaschine' with his colleagues, he was told that the idea had nothing new about it. ${ }^{94}$ On the other hand, the 'Gummi-Ringe' sent by Wilhelm, and which he presented to the assembly in 1846, were a 'sensation', and resulted in a manufacture showing interest. ${ }^{95}$ That same year, just as Wilhelm presented his Regulator to the Institution of Civil Engineers in London for similar purposes, Werner found 'a few enthusiasts with money and courage' for his artificial stones in the Polytechnische Gesellschaft. ${ }^{96}$

When one of Siemens' many competitors in this field presented his sub-par work to the assembly, he seized the opportunity and 'to entice others, I showed some samples which I had in my bag and which met with great approval [purely, he admitted, because they could not be examined thoroughly!]'. He was then approached by his principal competitor, the apothecary March. 'I want to be in contact with Herr March', he wrote to his brother, 'whose manufacture is currently on the upswing, as he has to turn away most of his orders'. ${ }^{97}$ In this, as in other cases, Werner realised the utility of his connection to the British market. Avoiding direct competition, he wondered whether 'perhaps in these circumstances we could make better business as an intermediary between [Herr March] and Ransome [their partner in England], than alone', ${ }^{98}$

The opportunities encountered in this way were a crucial function of the Polytechnische Gesellschaft, particularly in an environment no longer regulated by quotas, but by the demands of the market. The principal alternative organisations were the Gewerbeverein, whose ties to the state were likely to make it suspect with regards to patent protection, and the Korporation der Kaufmannschaft. The latter, however, established in 1820 as an organ for the representation of the 'merchant class', was characterised by a 
guild-like exclusivity. Even such prominent figures as Egells, among other machine manufacturers, remained outside the group. ${ }^{99}$ The Gesellschaft therefore provided a support network for entrepreneurs seeking both access to wider opportunities and the protection of common interests, foreshadowing the role of the specialised professional associations which would principally emerge in the 1850 s.

The association was part of a broader entrepreneurial network in which social connections secured a necessary degree of trust in an individual and his ideas, in the absence of former and formal structures of expertise. Werner Siemens was perfectly conscious of this fact. When trying to market and improve his brother's 'Regulator', he had sought out a number of well-known machine constructors who could trial the apparatus. Among those contacted and who used Wilhelm's invention at various times were Egells, Wöhlert, and even the Oppenheim Kattunfabrik. It was not self-evident, however, that the efficacy of a product would speak for itself. 'In order to do something with your Regulator here', Werner explained to his brother, 'you must send attestations from reputable technicians and manufacturers; because the fools here won't otherwise consider anything to be serious or good' ${ }^{100}$

It is no surprise, therefore, that a few months later Werner believed 'the Regulator will soon do better here, because I have won Borsig over to the idea' ${ }^{101}$ Connections and acquaintances were crucial, as Werner explained to Wilhelm: 'It is too difficult to convince people here of the necessity of producing things precisely, and they tend too much to condemn everything new, especially when it is of German origin and, moreover, not from a recognised master of the clique!'. ${ }^{102}$ These surrogate networks of trust stepped into the breach where no formal regulating authorities existed, particularly in the new machine construction industry. Social networks helped to establish credit structures, as they had done in late-eighteenth-century Britain, arguably signalling an imminent industrial 'take off'. ${ }^{103}$ 
Just as Werner sought out the contacts which would enable him to break into the relevant 'cliques', as his reputation grew he too came to function as a node, often a weak tie connecting his acquaintances to broader networks. In the case of Herr March, and others, business was to be made by mediating between Prussian and English markets. 'We have already achieved a Rennomée [sic] here', Werner wrote. 'There is constantly somebody turning to me either directly or indirectly who wants to propose an invention to be carried out in England. One could make a very nice business in this way! ${ }^{104}$ Baron von Schomberg, a Prussian publicist, even hoped that Wilhelm might gain him a position writing for The Times in London - the favour, Werner suggest, might well be repaid in the future. ${ }^{105} \mathrm{In}$ 1846, when searching for a position for his younger brother Ferdinand who was to become an estate owner and manager, Werner was even in contact with a Herr Savigny, 'the son of our noted minister'. The connection showed that he was at the very least in indirect contact with political circles, and prompted one of his few neutral remarks on developments in government, namely the soon disappointed belief that 'we will actually have a constitution now'. ${ }^{106}$

Through a number of key individuals, the state itself tapped into these entrepreneurial networks. Eventually, for instance, the Prussian Royal Mint expressed its interest in trialling the Siemens brothers' Regulator on their coining presses. Although there is no direct evidence of the specific arrangement reached, it is not unlikely that the opportunity arose from the Polytechnische Gesellschaft, whose founding father, Nathan Mendelssohn, was Stempel-Revisor and Chief inspector of the Royal Mint. Such opportunities were of crucial importance, both in terms of the credit they brought the entrepreneur in question, but also the possibility of trialling their invention. Siemens rightly believed that the offer to work with the Royal Mint 'would be an important step for us', and he understood the practical utility of the state's help, 'because no private individual here will hand over their machine for trials' ${ }^{107}$ 
The 1840s also saw the state Seehandlung wind up its activities, as the investment strategy pursued by its leader, Christian Rother, and intended to stimulate industrialisation, began to falter. Facing criticism over its interventionism, which had led it into direct competition with local businesses and was counter to the wishes of Beuth, the Seehandlung itself turned to these networks in the hope of finding redress. Werner read the situation and wanted 'to try and enter into closer contact with the Seehandlung', as 'in order to be in the public's good graces once more, [it] must change its entire system and truly protect and promote what is novel'. 'What could we not achieve with the financial resources of the institution $[\ldots]$ !' he exclaimed. ${ }^{108}$

His enthusiasm was sparked in 1845, when the Maschinenbau-Anstalt in Moabit, run by a graduate of the state's Gewerbe-Institut, faced financial ruin, and an offer was extended to Wilhelm to take over its management. The latter's background in a GewerbeSchule and as apprentice in the Stollberg'sche Fabrik no doubt recommended him for the position, but it was through an 'advocate' (Fürsprecher) - the commercial director of the machine factory - that Werner had been contacted about the opportunity for his brother. ${ }^{109}$ In this way, the state itself was utilising the available channels of communication and recommendation to reach independent entrepreneurs, thereby also opening up opportunities for them. By 1850, the Seehandlung had lost is operational freedom, and had handed over the reins of its undertakings to individuals such as Borsig, who bought the machine factory and state foundry. ${ }^{110}$

Throughout the period, meanwhile, the state's patenting process was a crucial bridge between public and private enterprise. The Technische Deputation itself, when managing these decisions, tended to be represented in the eyes of the entrepreneur by specific individuals. In the same way that one gained access to the entrepreneurial 'cliques' through renowned technicians, Werner Siemens was very clear that particular decisionmakers within the state had to be won over to his inventions. 
As a result, Beuth and Kommissions-Rat Adolph Brix are frequently evoked in his correspondence. The latter, moreover, was also a founding member and regular participant of the Polytechnische Gesellschaft, and therefore no doubt well known to Siemens. In order to obtain a long-lasting patent it was essential, he explained to his brother, 'to arouse the interest of Beuth and other chief figures (Hauptsöhne) and to show the matter in a very important light $[\ldots]$ therefore I want to show him samples and try to win him and Humbold [sic] over to the idea'. ${ }^{111}$ When the latter was in Berlin, it seems, he was the ideal sponsor for a new invention: regarding their patent on the production of artificial stones, in June 1845 Werner explained that 'as Humbold is here [...], it would now be the time to do something in the matter'. ${ }^{112}$

Living in Berlin during the early to mid-1840s, Siemens' connection to particular clusters of individuals thus embedded him in both military and entrepreneurial networks, in which the state positioned itself too. On one hand, Siemens occasionally struggled to reconcile his allegiances. 'In Berlin', he later wrote, 'my efforts to earn money through my inventions were soon successful, although they were rendered more difficult by the fact that, as an officer, my choice of means to institute businesses were very limited'. ${ }^{113}$ When he sought to establish a business around the production of artificial stones, therefore, he called for the involvement of a 'businessman' (Geschäftsmann), 'because I alone, particularly as long as I take the King's shilling (den bunten Rock trage), simply cannot do anything with it'. ${ }^{114}$

Yet Siemens also profited from the merging of his military and entrepreneurial connections, not least through his acquaintance with Hofrat Soltmann and Ferdinand Leonhardt - the latter, it seems, also a member of the Polytechnische Gesellschaft. And he was by no means the only officer involved in business. The long-standing steward of the Polytechnische Gesellschaft, for instance, was Oberst-Leutnant Professor Dr Turte, and one of Siemens' principal contacts in the printing business, was a certain 'Leutnant 
Baldamus', based in Hamburg. The General Staff, turning to one of its own, contacted Baldamus regarding the printing of maps and, perhaps unsurprisingly, Siemens was soon planning to present his own printing samples to the military authorities. ${ }^{115}$ When he then reconsidered his involvement in this branch, it was to Herr Delius, again 'a former bombardier of the Third Artillery Brigade', that he turned to offer his business. ${ }^{116}$ Although the evidence is anecdotal, Siemens' experience and contacts suggest that social networks rendered the boundaries of military institutions - particularly the artillery corps - and entrepreneurial circles more porous than is usually assumed, allowing for transfers between the two.

Siemens' letter of July 1846 points to a final, crucial Berlin-centred cluster, through which he would connect to scientific and entrepreneurial networks - the Physikalische Gesellschaft, for which, he explains, he had been writing a history of electrical telegraphy. ${ }^{117}$ The society was established in 1845 , and although Siemens almost immediately became a member, its role in shaping Siemens' career has rarely been acknowledged. ${ }^{118}$ This is all the more surprising as the list of its founding and participating members reads like a who's who of the German scientific academy as it was to develop by the end of the nineteenth century. Among its later most prominent personalities were Emil Du Bois-Reymond (b. 1818), Ernst Wilhelm Brücke (b. 1819), Hermann Helmholtz (b. 1821), Rudolf Clausius (b. 1822), Gustav Wiedemann (b. 1826), Carl Ludwig (b. 1816), Wilhelm Beetz (b. 1822) and Hermann Knoblauch (b. 1820). Siemens specifically singles out these young academics, all in their twenties at the time of the Gesellschaft's foundation, and thus roughly of his generation. ${ }^{119}$ Together, they formed a group of university-trained scientists, through whom Siemens gained limited access to the academy.

The Physikalische Gesellschaft grew out of the circle of around ten students whom Professor Gustav Magnus, at the University of Berlin, had invited to regular meetings at 
his house. From 1843, they assembled every week at Magnus' 'Private Laboratory', at am Kupfergraben 7 in the centre of town, and within a few minutes' walk of the university itself, to listen to a presentation and engage in discussion. ${ }^{120}$ Professor Magnus, who had taught Siemens at the VAIS, was the crucial link to the Gesellschaft. Around this time, Siemens had chosen to follow a series of lectures by Carl Jacobi at the University of Berlin, in an attempt to improve his scientific grounding. His regular presence there must have brought him once again to the attention of his former teacher, as well as other academics. And so Magnus invited him to join the 'inspiring social circle' of young, budding scientists who established the Physikalische Gesellschaft. ${ }^{121}$

Looking back on this period in his memoirs, Siemens believed that 'contact and collaboration with these young men [...] strengthened [his] preference for scientific studies and work, and awoke in [him] the decision later to serve only the cause of true science' ${ }^{122}$ Yet the list of the Gesellschaft's members, makes it clear that Siemens drew not only scientific, but also personal, professional and business connections from the group. For although it was nominally devoted to the 'progress of physics', the society represented a broad range of interests, and its membership was wide-ranging. Among its 53 members in 1845, for instance, were six 'mecanici' and six lieutenants -once again highlighting the connection of Prussian officers to broader social networks. In 1844, moreover, Siemens was listed as residing in the Artillerie-Werkstatt, am Kupfergraben 3-4, literally neighbouring Professor Magnus' home where the young students regularly assembled. By 1845 , he had moved to the barracks located on Luisenstraße, still no more than a short walk from the house. Circumstances thus enabled Werner to take part in the Gesellschaft's meetings as often as possible. ${ }^{123}$

The Physikalische Gesellschaft was characteristic of the specialised, local scientific associations which flourished during the second third of the nineteenth century. Although they were dedicated to the specific discipline of physics, from the outset the members welcomed talks and papers on a wider array of medical, scientific and technical 
subjects, somewhat like the Polytechnische Gesellschaft. The diversity of its initiating members confirms that they were open to most individuals with related interests. Clearly, these men felt a need for a wider-ranging discussion of scientific subjects, and the Gesellschaft thus distinguished itself from a university-orientated, academic colloquium. ${ }^{124}$ As expressed in the first edition of its publication, Fortschritte der Physik, prepared in 1845 but published in 1847, 'the intimate connection of the different branches of the natural sciences clearly demonstrates that disciplines which appear to be very distant from one another are in fact united in one'. ${ }^{125}$

The Physikalische Gesellschaft was a learned society, but the sociability which it rested upon and the friendships which it fostered contributed to the emergence of a selfconscious, educated middle-class. ${ }^{126}$ The importance of the social connections which it facilitated, especially in a small, yet rapidly transforming city such as Berlin, cannot be underestimated. Indeed, members included a certain 'Mechanicus Leonhard' as well as 'Dr. Soltmann', through whom Siemens thus multiplied his relations to entrepreneurial, military and scientific networks. ${ }^{127}$

Werner's background confirms his genuine, active interest in science, but it is clear that this ostensibly learned society served socio-economic functions too. Timothy Lenoir has even argued that the Physikalische Gesellschaft played a strategic role within the scientific academy itself. Focusing on one of its leading members - and crucially, a close friend of Werner Siemens - Emil Du Bois-Reymond, Lenoir suggests that the establishment of the society in the 1840s was part of a broader strategy of a group of young, university-trained scientists to establish the credentials of a new discipline, organic physics. Driven by their 'social interests', he argues, Helmoltz, Ludwig, Brücke and Du BoisReymond sought to exert pressure on the academy from without, by allying themselves with other 'outsiders', in particular the first generation of Berlin's entrepreneurs. ${ }^{128}$

Like the Polytechnische Gesellschaft, therefore, the society trod the line between a closed circle and an open network, serving both to strengthen bonds and forge new 
connections. Devoted on the one hand to furthering a particular scientific discipline and defending common interests, its members also depended upon their connections to other clusters of individuals to negotiate their position in a scientific network. Just as entrepreneurs and Handwerker were adjusting to the vagaries of the market, so 22 of the society's 54 earliest members were Privatdozenten, who faced a scarcity of tenured positions in the 1840s following the rise in university enrolment stimulated by the Reform Era. ${ }^{129}$ By associating, they sought contacts and security in a competitive market, and as a generation, their alliance foreshadowed the greater interaction between science and enterprise which would characterise Germany's later industrialisation.

It is also possible that the Physikalische Gesellschaft took on 'crypto-political' functions. No direct connection can be established, but it is perhaps no coincidence that among the founding members of the Fortschrittspartei in 1861, Siemens, Theodor Mommsen and Rudolf Virchow were all good friends of Emil Du Bois-Reymond. The latter's plan for a sweeping reform of the Academy of Sciences was applauded by liberals as a model for societal change and here too, politics cut across the social networks to which Siemens belonged. ${ }^{130}$

As a social-strategic 'alliance', the Physikalische Gesellschaft certainly served Siemens' interests too. When he came to review the observations he had made at Hofrat Soltmann's home in July 1846, Werner developed the Zeigertelegraph mit Selbstunterbrechung ['pointer telegraph with automatic interruption'] which was to make his name in the then germinating telegraph industry. Having initially entrusted the construction of the apparatus to his colleague Ferdinand Leonhardt, the partnership soon dissolved when the clockmaker obtained a patent and contracts of his own, becoming one of Siemens' principal competitors. ${ }^{131}$ After first approaching Johann August Oertling, a renowned Berlin mechanic who had worked with Alexander von Humboldt, and who was also a member of the Polytechnische Gesellschaft, it was then in the Physikalische Gesellschaft that he found a long-term collaborator. ${ }^{132}$ 
One of Oertling's apprentices, Johann Georg Halske, along with his business partner, Bötticher, were also both members of the society. As Emil Du Bois-Reymond was later to remark, he 'soon recognised that Halske was more than just a talented worker'. 'He possessed, to an unusual extent, the constructive talent, and had a flair for understanding scientific tasks, even without a learned education, and for finding the easiest and best way of carrying them out'. ${ }^{133}$ According to Du Bois-Reymond, although Halske and Siemens had no doubt crossed paths at the Gesellschaft's meetings before, he formally introduced them on $31^{\text {st }}$ December $1846 .{ }^{134}$ Siemens considered both Halske and Bötticher to be 'young, active, and educated people', but he soon drew the former away from his existing business, in order to establish the firm of Siemens \& Halske on 12th October 1847.

Werner Siemens' life after the establishment of the Telegraphen-Bauanstalt von Siemens \& Halske is well documented, and social networks continued to support his efforts in every domain. In the earliest years of the business, he experienced both the constraining and the liberating powers of these connections. As an officer, he was acquainted with key members of the state's Telegraphenkommission, which he was invited to consult for. By the same token, however, he and his partner decided that their business should be publicly presented under Halske's leadership, to avoid bringing attention to any preferential treatment he might receive. ${ }^{135}$

Siemens already intended to resign his position in service of the state at this stage, but chose to wait until the commission's projects for Prussia's future telegraph network were confirmed. He welcomed the outbreak of revolution in France in 1848, but once it reached Prussia he also insisted upon fulfilling his duties as an officer and served in Kiel against the Danish forces. The disturbances then encouraged the Prussian state to build one of its first telegraph lines from Berlin to Frankfurt am Main, and Siemens was called back to be entrusted with its construction. By June 1849, having established a reputation and firm financial basis for his business, he finally left both the army and the civil service. ${ }^{136}$ 
Throughout his life, by way of his position on the Telegraphenkommission, his authorship in technical and scientific journals, his role in founding the Fortschrittspartei in 1861, his support for Bismarck, his collaboration with Helmholtz in establishing the Physikalisch-Technische Reichsanstalt in 1887, and his ennoblement in 1888, Siemens maintained connections to crucial clusters of individuals. His family, meanwhile, continued to provide access to technical, logistical and financial resources at an ever greater distance. His cousin Johann Georg Siemens, a legal official, had provided an initial injection of 6,842 Thalers to fund the establishment of Siemens \& Halske. ${ }^{137}$ His brother Wilhelm remained in London, where the increasingly global Siemens Brothers would be established in 1858, and Carl would be sent to Saint-Petersburg to ensure the siblings dominated the development of telegraphy in the Russian Empire.

As time wore on and his status grew, like Beuth and Humboldt before him Siemens himself became a connecting personality between key groups in science, technology, business and even politics. The particular course which his own life had taken, however, was a product of the constellations which his connections had formed in Berlin during the 1840s. The growth, dynamism and layout of the city during this period facilitated the multiplication of overlapping relationships between individuals and their institutions, social circles, and families. The renewed vigour of Siemens' artillery regiment and its technological investigations, the state's growing reliance upon the private sector, and the support and protection which scientists and entrepreneurs needed in a market which still distinguished them as 'outsiders', placed greater value upon social networks as a means of reinforcing, but crucially also diversifying connections across state and society. As a means of negotiating uncertain socio-economic and political circumstances, they characterised what would later be understood as the end of 'early industrialisation' and the Vormärz in Prussia. 
*Unless otherwise stated, translations from sources are my own. 
${ }^{1}$ Werner von Siemens, Lebenserinnerungen, ed. W. Feldenkirchen (Munich, 2008), pp.84-5

${ }^{2}$ Werner to Wilhelm, 15th Jul. 1846, in Conrad Matschoß (ed.), Werner Siemens: Ein kurzgefaßtes

Lebensbild nebst einer Auswahl seiner Briefe (Berlin, 1916), pp.16-17

${ }^{3}$ ibid., 16

${ }^{4}$ ibid., 17

${ }^{5}$ Eric D. Brose, The Politics of Technological Change in Prussia: Out of the Shadow of Antiquity, 1809-1848 (Princeton, 1993), pp.98-132; Wolfhard. Weber, 'Preussische Transferpolitik 1780 bis 1820', Technikgeschichte, vol. 50 (1983), pp.181-196

${ }^{6}$ Siemens, Lebenserinnerungen, 83-4

7 Thomas Nipperdey, Germany from Napoleon to Bismarck, 1800-1866, transl. Daniel Nolan (Princeton, NJ, 1996), p.159; Hans-Ulrich Wehler, Deutsche Gesellschaftsgeschichte (5vols., Munich, 1987-2008), ii., 636

${ }^{8} \mathrm{~A}$ recent rich contribution to the debate on the respective roles of science and 'know-how' is P. M. Jones, Industrial Enlightenment: Science, Technology and Culture in Birmingham and the West Midlands, 1760-1820 (Manchester, 2013); Kees Gispen, New Profession, Old Order: Engineers and German Society, 1815-1914 (Cambridge, 1989)

${ }^{9}$ An observation put forward forcefully and elegantly by Jonathan Sperber in Karl Marx: A Nineteenth-Century Life (New York, 2014)

${ }^{10}$ William O. Henderson, The State and the Industrial Revolution in Prussia (Liverpool, 1958); Ulrich Peter Ritter, Die Rolle des Staats in den Frühstadien der Industrialisierung (Berlin, 1961); Wolfram Fischer, Der Staat und die Anfänge der Industrialisierung in Baden, 1800-1850 (Berlin, 1962); Wilhelm Treue, Wirtschafts- und Technikgeschichte Preussens (Berlin, 1984)

${ }^{11}$ Wilhelm Treue, 'Das Verhältnis von Staat und Wirtschaft in Deutschland am Beginn der Industrialisierung', Kyklos, vol. 14, no. 3 (1961), pp. 337-63

${ }^{12}$ Ilja Mieck, Preussische Gewerbepolitik in Berlin, 1806-1844 (Berlin, 1965)

${ }^{13}$ Wehler, Deutsche Gesellschaftsgeschichte, ii., 69

${ }^{14}$ Treue, Wirtschafts- und Technikgeschichte, p. 329

${ }^{15}$ Jürgen Kocka, Unternehmer in der deutschen Industrialisierung (Götingen, 1975)

${ }^{16}$ Hartmut Kaelble, Berliner Unternehmer während der frühen Industrialisierung (Berlin, 1972)

${ }^{17}$ Peter Lundgreen, Techniker in Preussen während der Frühindustrialisierung (Berlin, 1975); Lars Ulrich Scholl, Ingenieure in der Frühindustrialisierung (Göttingen, 1978)

${ }^{18}$ Jonathan Sperber, 'Bürger, Bürgertum, Bürgerlichkeit, Bürgerliche Gesellschaft: Studies of the German (Upper) Middle Class and Its Sociocultural World', The Journal of Modern History 69, no.2 (1997), pp.272-97

19 Siemens, Lebenserinnerungen, 9; In Kaelble's study of Berlin entrepreneurs, for instance, Siemens repeatedly (tacitly) features as an outlier: Berliner Unternehmer, pp. 30-54

${ }^{20}$ Matscho $\beta$, Werner Siemens; Artur Fürst, Werner von Siemens: Der Begründer der modernen Elektrotechnik (Berlin, 1916)

${ }^{21}$ Wilfried Feldenkirchen, Werner von Siemens: Erfinder und internationaler Unternehmer, (Munich, 1996) 
22 Jürgen Kocka, 'Unternehmensverwaltung und Angestelltenschaft am Beispiel Siemens 18471914: zum Verhältnis von Kapitalismus und Bürokratie in der deutschen Industrialisierung' (Dissertation, Berlin, 1969), p.55

${ }^{23}$ Joanna Innes, 'Networks in British History', The East Asian Journal of British History, vol. 5 (March 2016), pp.51-72, provides a clear and concise overview of the different historiographical applications of networks.

${ }^{24}$ Mark Granovetter, 'The Strength of Weak Ties', American Journal of Sociology vol. 78, no. 6 (1973), pp. 1360-80; Charles Kadushin, in Understanding Social Networks: Theories, Concepts, Findings (New York, 2012), esp. pp. 108-34

${ }^{25}$ Brose, Politics

${ }^{26}$ James M. Brophy, Capitalism, Politics, and Railroads in Prussia, 1830-1870 (Columbus, 1998)

${ }^{27}$ Lawrence Brockliss, Calvet's Web: Enlightenment and the Republic of Letters in EighteenthCentury France (Oxford, 2002); Anne Baillot (ed.), Netzwerke des Wissens: Das intellektuelle Berlin um 1800 (Berlin, 2011)

${ }^{28}$ Brian Vick, The Congress of Vienna: Power and Politics after Napoleon (London, 2014), p. 138

${ }^{29}$ Hartmut Berghoff and Jörg Sydow (eds.), Unternehmerische Netzwerke: Eine historische Organisationsform mit Zukunft? (Stuttgart, 2007); Robin Pearson and David Richardson, 'Business Networks in the Industrial Revolution', Economic History Review vol.54, no.4 (Nov. 2001), pp.657679; Christian W. Johnson, David Warren Sabean, Simon Teuscher and Francesca Trivellato (eds.), Transregional and Transnational Families in Europe and Beyond (Oxford, 2011)

${ }^{30}$ Johannes Bähr, Werner von Siemens, 1816-1892 (Munich, 2016); Martin Lutz, Carl von Siemens, 1829-1906: Ein Leben zwischen Familie und Weltfirma (Munich, 2013); Cf. also Jürgen Kocka 'Family and Bureaucracy in German Industrial Management, 1850-1914: Siemens in Comparative Perspective', Business History Review, vol. 45 (1971), pp. 133-56

${ }^{31}$ As Adelheid von Saldern has shown in her study of the Schoeller dynasty of cloth and paper manufacturers in the Eifel region: Adelheid von Saldern, Netzwerkökonomie im frühen 19. Jahrhundert (Stuttgart, 2009)

32 Jerrold Seigel, Modernity and Bourgeois Life: Society, Culture and Politics in England, France and Germany since 1750 (Cambridge, 2012)

${ }^{33}$ James M. Brophy, 'The End of the Economic Old Order: the Great Transition, 1750-1860', in Helmut Walser Smith (ed.), The Oxford Handbook of Modern German History (Oxford, 2011), pp. 169-94

${ }^{34}$ A conclusion also drawn by Johannes Bähr in Werner von Siemens, p. 80

${ }^{35}$ Horst A. Wessel, Die Entwicklung des elektrischen Nachrichtenwesens in Deutschland und die rheinische Industrie (Wiesbaden, 1983), pp.141-206

${ }^{36}$ Allgemeiner Wohnungsanzeiger für Berlin, Charlottenburg und Umgebungen (Berlin, 1845), p.446; Gerhard König, Uhren und Uhrmacherei in Berlin, 1450-1900 (Berlin, 1988), p.59

${ }^{37}$ Siemens, Lebenserinnerungen, 49

${ }^{38}$ Lundgreen, Techniker, 45-134

${ }^{39}$ Kaelble, Berliner Unternehmer, 39 
40 Jürgen Kocka, Industrial Culture \& Bourgeois Society (Oxford, 1999), p.82; cf. also Christian Helfer, 'Über militärische Einflüße auf die industrielle Entwicklung in Deutschland', Schmollers Jahrbuch (1963), pp.597-609;

${ }^{41}$ Siemens, Lebenserinnerungen, 59; Ute Frevert, Men of Honour: A Social and Cultural History of the Duel (Cambridge, 1995), pp.36-134

${ }^{42}$ Siemens, Lebenserinnerungen, 60

${ }^{43}$ Siemens, Lebenserinnerungen, 60; Christian Ferdinand Siemens to his son Werner, Mar. 21, 1839, S[iemens] C[orporate] A[rchives] (henceforth SCA) F2315

${ }^{44}$ Kocka, Unternehmer, 39

${ }^{45}$ Brose, Politics, 164-89; Dennis Showalter, Railroads and Rifles: Soldiers, Technology and the Unification of Germany, (Hamden, Conn., 1975), pp. 143-60

${ }^{46}$ Brose, Politics, 170

${ }^{47}$ Showalter, Railroads, 143-8

${ }^{48}$ Siemens, Lebenserinnerungen, 112

${ }^{49}$ Siemens, Lebenserinnerungen, 143

50 Johann Peter Kux, Organismus und vollständige Statistik des Preussischen Staats aus zuverlässigen Quellen (Berlin, 1840), p.35

${ }^{51}$ Christina Jungnickel \& Russell McCormmach, Intellectual Mastery of Nature: Theoretical Physics from Ohm to Einstein (2 vols., 1986), vol. 1, The Torch of Mathematics, 1800-1870, pp. 3462

${ }^{52}$ Showalter, Railroads, 151-60

${ }^{53}$ Brose, Politics, pp. 133-63

54 These patent applications run through almost nine volumes in the Geheimes Staatsarchiv Preussischer Kulturbesitz: G[eheimes] St[aats]A[rchiv Preussischer Kulturbesitz], I.HA Rep.120 MfHuG, D XIV 2 Nr.16 Bd.1-9

${ }^{55}$ May 10, 1842, GStA I. HA Rep.120 MfHuG D XIV 2 Nr. 16, Bd.1,

${ }^{56}$ Siemens, Lebenserinnerungen, 63

${ }^{57}$ Matschoß, Lebensbild, i., 9

${ }^{58}$ Werner to Wilhelm, Jun. 26, 1841, Matscho $\beta$, Briefe, 4

${ }^{59}$ Carl Soltmann to Werner, 1842, SAA A220

${ }^{60}$ Siemens, Lebenserinnerungen, p.73

${ }^{61}$ On Wilhelm's work and collaboration with Werner, see William Pole, The Life of Sir William Siemens (London, 1888)

${ }^{62}$ Wilhelm to Werner, Aug. 29, 1842, SCA W1786

${ }^{63}$ Werner to Wilhelm, Sep. 29, 1842, SAA W 8517

${ }^{64}$ Kocka, Unternehmer, 40

${ }^{65}$ Mieck, Preussische Gewerbepolitik, 146

${ }^{66}$ Ingrid Thienel, Städtewachstum im Industrialisierungsprozess des 19. Jahrhunderts: Das Berliner Beispiel (Berlin, 1973), pp. 85 \& 369

${ }^{67}$ Kaelble, Berliner Unternehmer, pp. 77-146 
${ }^{68}$ Nadja Stulz-Herrnstadt, Berliner Bürgertum im 18. Und 19. Jahrhundert (Berlin 2002), pp.27186

${ }^{69}$ Paul Craven and Barry Wellman, 'The Network City', Sociological Inquiry, vol. 43, nos. 3-4 (1973), pp. 57-88

${ }^{70}$ Seigel, Modernity

${ }^{71}$ Allgemeiner Wohnungsanzeiger (Berlin, 1843), p. 518; Allgemeiner Wohnungsanzeiger (Berlin, 1844), p.447; Allgemeiner Wohnungsanzeiger (Berlin, 1845), p. 443

${ }^{72}$ Mario Krammer, Berlin im Wandel der Jahrhunderte (Berlin, 1956), pp.133-178

${ }^{73}$ Lebenserinnerungen, $86-90$

${ }^{74}$ Jochen Boberg, Tilman Fichter \& Eckhart Gillen (eds.), Exerzierfeld der Moderne: Industriekultur in Berlin im 19. Jahrhundert (1984), pp.52-5

${ }^{75}$ Werner to Wilhelm, Mar. 1, 1846, SCA W1575

${ }^{76}$ Entry for Nathan Mendelssohn on Deutsche-Biographie.de [https://www.deutschebiographie.de/gnd137019254.html] (Oct. 12, 2016)

${ }^{77}$ Mieck, Preussische Gewerbepolitik, 162

${ }^{78}$ Despite the importance of the Polytechnische Gesellschaft to Siemens' development as both innovator and entrepreneur, it is mentioned only in passing in both Feldenkirchen's and Johannes Bähr's biographies.

${ }^{79}$ See the certificate commemorating the 50th anniversary of his joining, SCA GU 16.

${ }^{80}$ Bericht über die Wirksamkeit und die Verhältnisse der Polytechnischen Gesellschaft zu Berlin (7 vols., Berlin, 1845-50), ii., 11

${ }^{81}$ A private theatre company, unrelated to the later astronomical society.

${ }^{82}$ Bericht..., iii., pp. 3 \& 33

${ }^{83}$ Werner to Wilhelm, Oct. 1, 1844, SCA W8522; Bericht..., iii., 111

${ }^{84}$ David Lux \& Harold Cook, 'Closed Circles or Open Networks?: Communicating at a Distance during the Scientific Revolution', History of Science vol. 36, no. 2 (June 1998), pp.179-211

${ }^{85}$ Bericht..., ii., 57 \& iv., 65

${ }^{86}$ ibid., iii., 31

${ }^{87}$ ibid., iii., 15

88 ibid., ii., 6

${ }^{89}$ ibid., iii., 2 \& i., $1-3$

${ }^{90}$ Mieck, Preussische Gewerbepolitik, 207-224

${ }^{91}$ Margrit Seckelmann, Industrialisierung, Internationalisierung und Patentrecht im Deutschen Reich, 1871-1914 (Frankfurt am Main, 2006), 57-106

${ }^{92}$ Ludwig Fischer, Werner Siemens und der Schutz der Erfindungen (Berlin, 1922), p. 20

${ }^{93}$ Werner to Wilhelm, Apr. 2, 1845, SCA W8525

${ }^{94}$ Bericht..., iv., 30

${ }^{95}$ Werner to Wilhelm, Mar. 4, 1846, SCA W8549

${ }^{96}$ Pole, William Siemens, 53; Werner to Wilhelm, May 20, 1846, SCA W1581

${ }^{97}$ Werner to Wilhelm, Jul. 27, 1845, SCA W8534 
98 ibid.

99 Hans-Peter Helbach, 'Berliner Unternehmer in Vormärz und Revolution 1847-1848', in Untersuchungen zur Geschichte der frühen Industrialisierung vornehmlich im Wirtschaftsraum Berlin/Brandenburg, ed. O. Büsch (Berlin, 1971), 420-35

${ }^{100}$ Werner to Wilhelm, Sep. 25, 1845, SCA W8539

${ }^{101}$ Werner to Wilhelm, Oct. 9, 1845, SCA W8540

${ }^{102}$ Werner to Wilhelm, Dec. 11, 1845, SCA W8545

103 Pearson \& Richardson, 'Business Networks'

${ }^{104}$ Werner to Wilhelm, Jun. 9, 1845, SCA W8530

${ }^{105}$ Werner to Wilhelm, May 21, 1845, SCA W8529

106 Werner to Wilhelm, April 16, 1846, SCA W1579

${ }^{107}$ Werner to Wilhelm, May 20, 1846, SCA W1581

${ }^{108}$ Werner to Wilhelm, Jul. 27, 1845, SCA W8534

109 ibid.

${ }^{110}$ Mieck, Preussische Gewerbepolitik, 204-6

${ }^{111}$ Werner to Wilhelm, Apr. 16, 1845, SCA W8526

${ }^{112}$ Werner to Wilhelm, Jun. 26, 1845, SCA W8532

113 Siemens, Lebenserinnerungen, 72

${ }^{114}$ Werner to Wilhelm, Sep. 10, 1846, SCA W1589

${ }^{115}$ Werner to Wilhelm, Dec. 11, 1845, SCA W8545

116 Werner to Wilhelm, Mar. 4, 1846, SCA W8549

${ }^{117}$ Published in G. Karsten, Die Fortschritte der Physik (Berlin, 1847), pp.552-66

118 Among Siemens' biographers, only Johannes Bähr briefly discusses the society’s influence upon Werner's career, in Werner von Siemens, chap. 3

119 Siemens, Lebenserinnerungen, 79

120 Wolfgang Schreier, Martin Frankeunter, and Annett Fiedler, 'Geschichte Der Physikalischen Gesellschaft Zu Berlin 1845-1900', Physikalische Blätter 51, no. 1 (1995), p.11

${ }^{121}$ Siemens, Lebenserinnerungen, 79

122 ibid.

${ }^{123}$ Allgemeiner Wohnungsanzeiger (Berlin, 1844 \& 1845)

124 ,Geschichte der Physikalischen Gesellschaft', 14

${ }^{125}$ Karsten, Fortschritte der Physik, viii-ix

126 Thomas Nipperdey, 'Verein als soziale Struktur in Deutschland im späten 18. Und frühen 19. Jahrhundert. Eine Fallstudie zur Modernisierung', in Gesellschaft, Kultur, Theorie: Gesammelte Aufsätze zur neueren Geschichte (Göttingen, 1976), pp. 174-205

${ }^{127}$ Karsten, Fortschritte der Physik, viii

128 Timothy Lenoir, Instituting Science: The Cultural Production of Scientific Disciplines (Stanford University Press, 1997), pp. 75-95

129 ibid., 84; Konrad Jarausch, 'The Sources of German Student Unrest 1815-1848', in Lawrence Stone (ed.), The University in Society (Princeton, 1974), vol.2, pp. 533-70 
130 ibid., 88

${ }^{131}$ Werner to Wilhelm, Dec. 11, 1846, SCA W1593; cf. Leonhardt's patent request on Sep. 3, 1846, in GStA I. HA Rep. 120 MfHuG D XIV 2 Nr. 16, Bd. 1

132 Emil Du Bois-Reymond, ,Nachruf an Johann Georg Halske', in Verhandlungen der Physikalischen Gesellschaft zu Berlin im Jahre 1890, ed. A. König (Berlin, 1891), p. 42

${ }^{133}$ ibid., 40

134 ibid., 42

${ }^{135}$ Bähr, Werner von Siemens, chap. 4

${ }^{136}$ Feldenkirchen, Werner von Siemens, pp. 54-70

137 ibid., p. 66 